\title{
Failure to heal vitamin D-deficiency rickets and suppress secondary hyperparathyroidism with conventional doses of 1,25-dihydroxy vitamin $\mathrm{D}_{3}$
}

\author{
T CUNDY, J A KANIS, G HEYNEN, M EARNSHAW, T L CLEMENS, J L H O'RIORDAN, \\ A L MERRETT, J E COMPSTON
}

The actions of 1,25-dihydroxy vitamin $\mathrm{D}_{3}\left(1,25(\mathrm{OH})_{2} \mathrm{D}_{3}\right)$ are thought to account for most of the known effects of vitamin $D$, and defective production and low plasma concentrations of $1,25(\mathrm{OH})_{2} \mathrm{D}_{3}$ are frequently associated with osteomalacia and secondary hyperparathyroidism. ${ }^{1}$ Exogenous $1,25(\mathrm{OH})_{2} \mathrm{D}_{3}$ (or its synthetic analogue $1 \alpha$-hydroxy vitamin $\mathrm{D}_{3}$ ) has been given successfully in doses close to its physiological rate of production - $0.3-1.0 \mu \mathrm{g}$ daily - to treat patients who have osteomalacia and hyperparathyroidism accompanied by dietary vitamin D deficiency, chronic liver disease, treatment with anticonvulsant drugs, chronic renal failure, and vitamin D-dependent rickets (type I)..$^{2-7}$

Despite the association of defective mineralisation of bone and hyperparathyroidism with low concentrations of $1,25(\mathrm{OH})_{2} \mathrm{D}_{3}$, and the ability of $1,25(\mathrm{OH})_{2} \mathrm{D}_{3}$ to reverse these abnormalities, it is not clear whether these effects of $1,25(\mathrm{OH})_{2} \mathrm{D}_{3}$ are due to direct actions on bone or the parathyroid glands or whether they are mediated indirectly by changes induced in extracellular calcium and phosphorus concentrations or in other vitamin D metabolites.

We report on a patient with severe osteomalacia and secondary hyperparathyroidism whose response to treatment with $1,25(\mathrm{OH})_{2} \mathrm{D}_{3}$ was critically dependent on the calcium in his diet.

\section{Case report}

A 19-year-old Pakistani man, who had lived in England for four years, presented with a one-year history of bone pain in the rib cage and legs and proximal muscle weakness. He and his family ate a traditional diet including bread made from chapatti flour, but there was no family history of bone disease. His daily calcium intake was estimated to be $10 \mathrm{mmol}(400 \mathrm{mg})$ and vitamin $\mathrm{D}$ intake $1 \mu \mathrm{g}$ (UK recommended daily intake: $12.5-15 \mathrm{mmol}$ $\left(500-600 \mathrm{mg}\right.$ ) and $2.5 \mu \mathrm{g}$ respectively $\left.^{8}\right)$. Apart from local rib

\footnotetext{
Nuffield Departments of Medicine and Orthopaedic Surgery, University of Oxford

T CUNDY, MRCP, clinical research fellow

J A KANIS, MRCP, Wellcome senior clinical fellow

G HEYNEN, MD, charge de recherche

M EARNSHAW, PHD, postdoctoral research fellow

Department of Medicine, Middlesex Hospital, London

T L CLEMENS, PHD, research fellow

J L H O'RIORDAN, FRCP, reader

Gastrointestinal Research Unit, St Thomas's Hospital, London A L MERRETT, BSC, research assistant

J E COMPSTON, MD, senior research registrar
}

\begin{abstract}
Vitamin D-deficiency rickets and secondary hyperparathyroidism may not respond to 1,25 dihydroxy vitamin $D_{3}$ unless the diet is supplemented with calcium
\end{abstract}

tenderness and proximal myopathy, the physical examination was normal. His height $(176 \mathrm{~cm})$ and weight $(47 \cdot 8 \mathrm{~kg})$ were normal for his age.

Investigations showed severe osteomalacia and moderate chronic renal failure; the glomerular filtration rate (measured as endogenous creatinine clearance) was reduced to $14 \mathrm{ml} / \mathrm{min}$. The following investigations were normal: proteinuria, micturating cystourethrogram, intravenous urography of the kidneys, barium examination of the upper gastrointestinal tract, and absorption of fat from a standard fatty meal. ${ }^{9}$ A percutaneous renal biopsy showed an "end-stage" appearance, with prominent interstitial fibrosis of uncertain aetiology. There was no evidence of malabsorption due to gastrointestinal disease. $X$-ray examination of the skeleton showed rachitic changes at the humeral heads and acromioscapular epiphyses (fig 1). There were also marked subperiosteal erosions of the phalanges, clavicles, and pelvis, a pseudofracture in one rib, and osteosclerosis throughout the skeleton. Plasma concentrations of 25-hydroxyvitamin $\mathrm{D}_{3}\left(25-\mathrm{OHD}_{3}\right)$ and $1,25(\mathrm{OH})_{2} \mathrm{D}_{3}$ were low, and plasma concentrations of alkaline phosphatase, hydroxyproline, and immunoreactive parathyroid hormone were raised (table).

A transiliac bone biopsy taken under local anaesthesia (Bordier $8 \mathrm{~mm}$ trephine) confirmed severe osteomalacia and secondary hyperparathyroidism. Osteoid occupied $66 \%$ of the total matrix area and covered $95 \%$ of trabecular surfaces. Up to 18 birefringent osteoid lamellae were visible under polarised light. ${ }^{10}$ There was also dissecting bone resorption and patchy marrow fibrosis.

We began treatment with $1,25(\mathrm{OH})_{2} \mathrm{D}_{3} 3 \mu \mathrm{g}$ daily, ferrous sulphate $200 \mathrm{mg}$ daily, and sodium bicarbonate $1 \cdot 8-2 \cdot 4 \mathrm{~g}$ daily. His plasma calcium concentration rose after 32 weeks to normal (fig 2 ; table), but his plasma alkaline phosphatase, hydroxyproline, and immunoreactive parathyroid hormone concentrations did not fall, despite increasing the dose of $1,25(\mathrm{OH})_{2} \mathrm{D}_{3}$ to $5 \mu \mathrm{g}$ daily. Indeed, they increased while he was being treated, suggesting that the bone disease was progressing. There was also little improvement in his symptoms.

We investigated the possible reasons for his apparent resistance to $1,25(\mathrm{OH})_{2} \mathrm{D}_{3}$ treatment. He took and absorbed the drug since plasma samples taken at outpatient visits during treatment showed normal or high concentrations of $1,25(\mathrm{OH})_{2} \mathrm{D}_{3}$. Moreover, plasma calcium concentrations fell on two occasions when treatment was temporarily stopped (fig 2), indicating that 
$1,25(\mathrm{OH})_{2} \mathrm{D}_{3}$ was having some biological effects. In addition, a calcium absorption test after 32 weeks showed a very high fractional calcium absorption ( $52 \%$; range in uraemia $3-28 \%$ ), suggesting that $1,25(\mathrm{OH})_{2} \mathrm{D}_{3}$ was acting, as expected, on the intestinal mucosa.
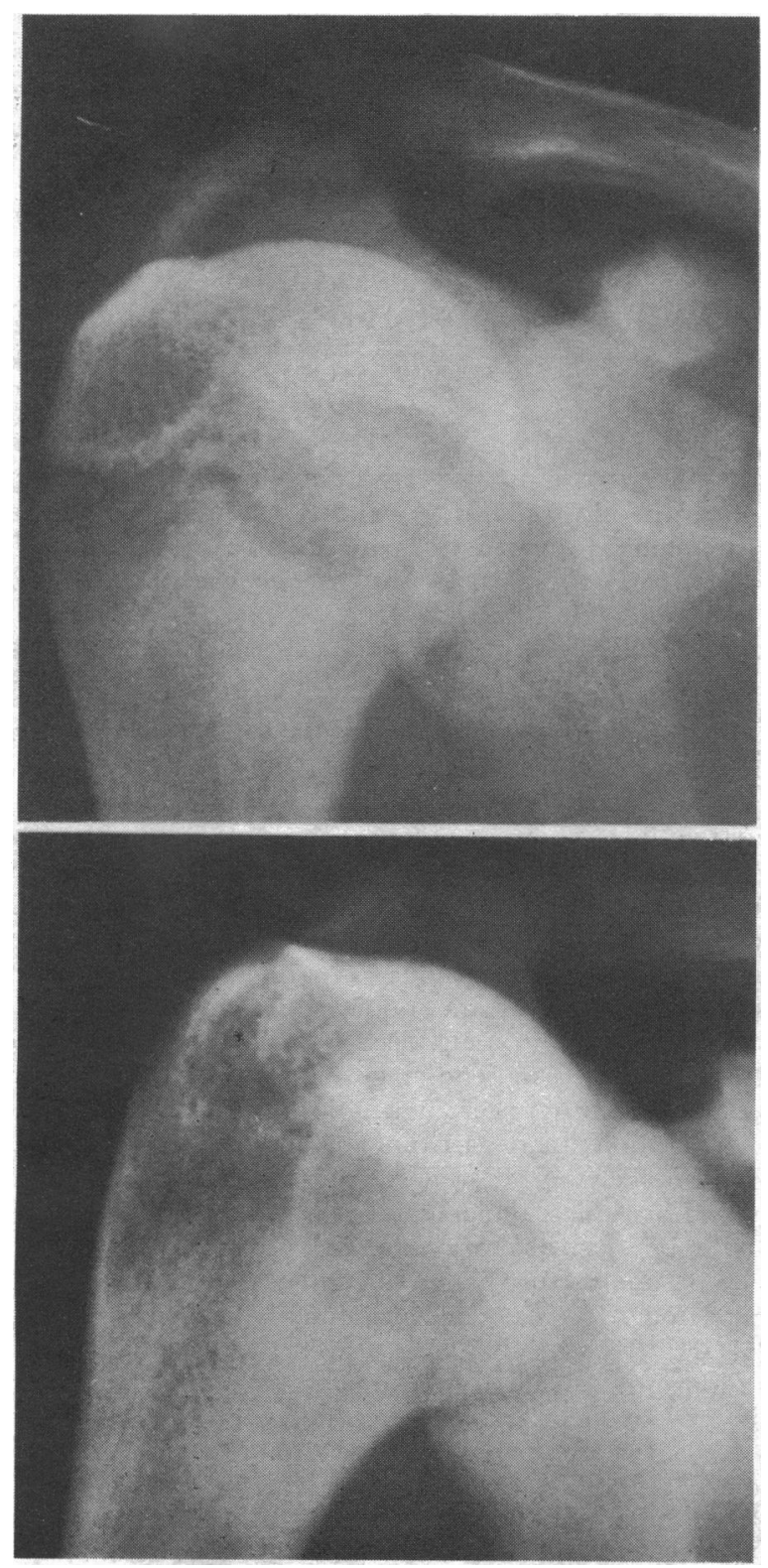

FIG 1-Radiographic appearances of the right shoulder before (left) and after treatment (right), showing the healing of the widened epiphyseal seam.

In trying to find the reason for his apparent resistance to $1,25(\mathrm{OH})_{2} \mathrm{D}_{3}$ we decided that his diet contained insufficient calcium, and he was given Sandocal, which provided $40 \mathrm{mmol}$ elemental calcium daily. This caused the plasma calcium concentrations to rise, plasma alkaline phosphatase, immunoreactive parathyroid hormone, and hydroxyproline concentrations to fall (fig 2), and the symptoms to abate. After 46 weeks of calcium supplements, $x$-ray films of the skeleton showed the loss of subperiosteal erosions and the healing of epiphyseal abnormalities (fig 1), but osteosclerosis had increased. A repeat bone biopsy showed that the osteomalacia had healed completely.

The dose of $1,25(\mathrm{OH})_{2} \mathrm{D}_{3}$ was progressively decreased to $0.5 \mu \mathrm{g}$ daily to avoid hypercalcaemia. The osteomalacia had healed

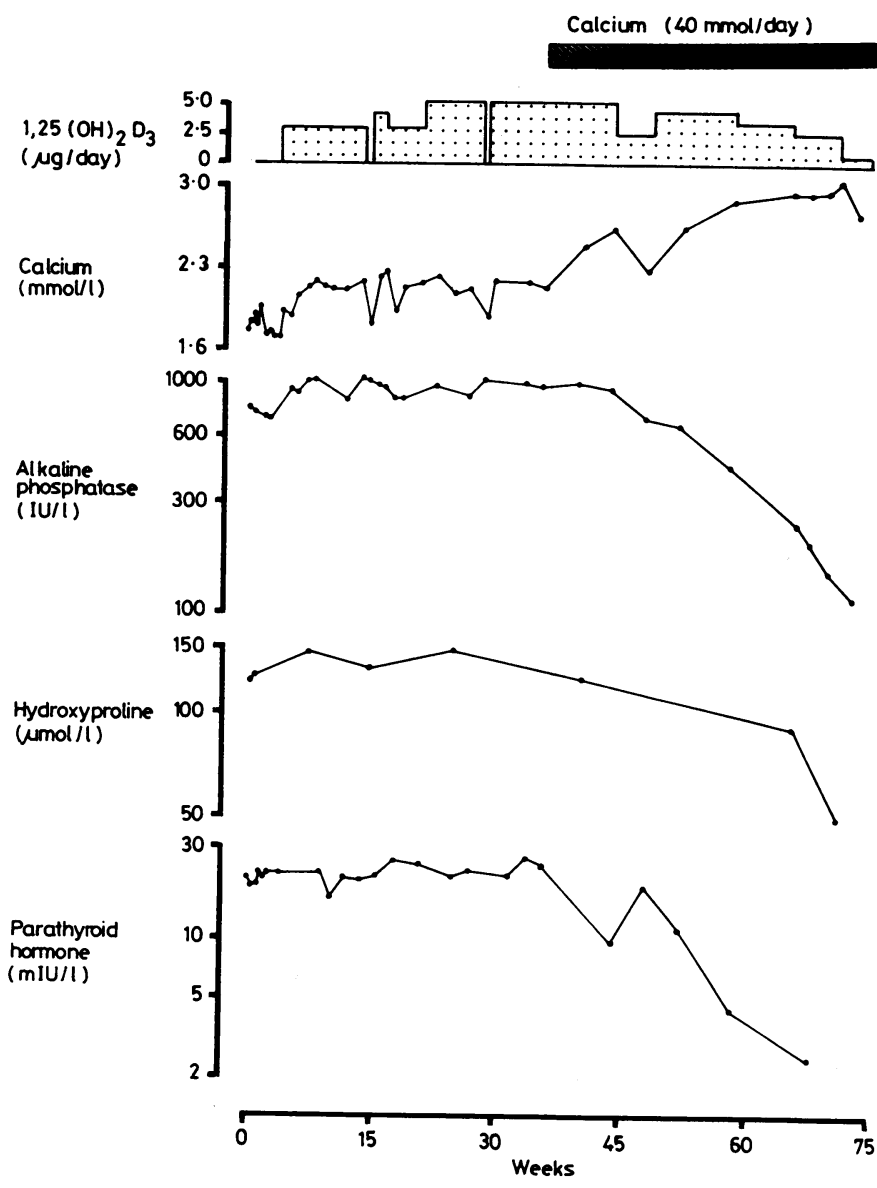

FIG 2-Biochemical measurements on plasma in response to treatment with 1,25-dihydroxycholecalciferol $\left(1,25(\mathrm{OH}), \mathrm{D}_{3}\right)$. Note the logarithmic scale for plasma hydroxyproline, alkaline phosphatase, and immunoreactive parathyroid hormone.

Conversion: SI to traditional units-Plasma calcium: $1 \mathrm{mmol} / 1 \approx 4 \mathrm{mg} / 100$ mg. Plasma hydroxyproline: $1 \mu \mathrm{mol} / 1 \approx 13 \cdot 1 \mu \mathrm{g} / 100 \mathrm{ml}$.

Results of biochemical tests before and during treatment

\begin{tabular}{|c|c|c|c|c|}
\hline & $\begin{array}{c}\text { At } \\
\text { presentation }\end{array}$ & $\begin{array}{c}\text { After } 32 \\
\text { weeks: } \\
1,25(\mathrm{OH})_{2} \mathrm{D}_{3} \\
\text { alone }\end{array}$ & $\begin{array}{c}\text { After } 36 \\
\text { weeks: } \\
1,25(\mathrm{OH})_{2} \mathrm{D}_{3} \\
\text { and calcium } \\
\text { supplements }\end{array}$ & $\begin{array}{l}\text { Normal } \\
\text { range }\end{array}$ \\
\hline $\begin{array}{l}\text { Calcium (mmol/l) } \\
\text { Phosphate (mmol/1) } \\
\text { Creatinine (mmol/1) }\end{array}$ & $\begin{array}{l}1.70 \\
1.30 \\
0.56\end{array}$ & $\begin{array}{l}2.16 \\
1.62 \\
0.65\end{array}$ & $\begin{array}{l}2.70 \\
1.42 \\
0.89\end{array}$ & $\begin{array}{l}2 \cdot 12-2 \cdot 65 \\
0 \cdot 80-1 \cdot 40 \\
0 \cdot 06-0 \cdot 14\end{array}$ \\
\hline $\begin{array}{l}\text { (IU/1) } \\
\text { Hydroxyproline }\end{array}$ & 759 & 980 & 116 & $20-120$ \\
\hline $\begin{array}{l}(\mu \text { mol } / 1) \\
\text { Immunoreactive } \\
\text { parathyroid }\end{array}$ & 122 & 151 & 51 & $3-17$ \\
\hline $\begin{array}{c}\text { hormone }(\mathrm{U} / \mathrm{l}) \\
25-\mathrm{OHD},(\mathrm{nmol} / \mathrm{l}) \\
1,25(\mathrm{OH}), \mathrm{D}_{3}\end{array}$ & $21 \cdot 0$ & $\begin{array}{c}22 \cdot 0 \\
10\end{array}$ & $\begin{array}{r}4 \cdot 4 \\
11\end{array}$ & $\begin{array}{l}2 \cdot 6-4 \cdot 8 \\
20-100\end{array}$ \\
\hline$(\mathrm{pmol} / \mathrm{l})^{\mathrm{D}_{8}}$ & Undetectable & 133 & 308 & $50-125$ \\
\hline
\end{tabular}

Conversion: SI to traditional units-Calcium: $1 \mathrm{mmol} / 1 \approx 4 \mathrm{mg} / 100 \mathrm{ml}$. Phosphate: $\mathrm{mmol} / 1 \approx 3 \mathrm{mg} / 100 \mathrm{ml}$. Creatinine: $1 \mathrm{mmol} / 1 \approx 0.0113 \mathrm{mg} / 100 \mathrm{ml}$. Hydroxyproline: $1 \mu \mathrm{mol} / 1 \approx 13.1 \mu \mathrm{g} / 100 \mathrm{ml}$. $25-\mathrm{OHD}_{3}$ and $1,25(\mathrm{OH})_{2} \mathrm{D}_{3}: 1 \mathrm{nmol} / 1 \approx 0.4 \mathrm{ng} / \mathrm{ml}$.

without any definite increase in $25-\mathrm{OHD}_{3}$ concentrations and despite a progressive decline in renal function (fig 1 , table), which was not affected by $1,25(\mathrm{OH})_{2} \mathrm{D}_{3}$ treatment or by calcium supplements.

\section{Discussion}

Several factors may have contributed to our patient's severe bone disease, including his age, a low dietary intake of vitamin $\mathrm{D}$, and a high intake of chapatti flour. ${ }^{11} \mathrm{He}$ also had appreciable 
renal impairment, though this alone was unlikely to have accounted for the severe osteomalacia. Irrespective of the mechanisms concerned his bone disease was probably due in part to deficient production of the active metabolites of vitamin $\mathrm{D}$. The unusual feature of this patient was that he failed to respond to treatment with a large dose-3 $\mu \mathrm{g}-$ of $1,25(\mathrm{OH})_{2} \mathrm{D}_{3}$, which was given because of his severe bone disease and profound hypocalcaemia. The usual maintenance dose is approximately $0.25-0.5 \mathrm{ug}$ daily in chronic renal failure. ${ }^{6} \mathrm{He}$ also failed to respond to an increase to $5 \mu \mathrm{g}$ daily; and only when calcium supplements were given did he begin to respond.

Previous reports of $1,25(\mathrm{OH})_{2} \mathrm{D}_{3}$ "resistance" have been ascribed to end-organ insensitivity-either acquired, as in coeliac disease, ${ }^{12}$ or congenital, as in vitamin D-dependent rickets type II. ${ }^{13-17}$ But in this patient the gut responded appropriately to high doses of $1,25(\mathrm{OH})_{2} \mathrm{D}_{3}$, and when calcium supplements were given the dose had to be reduced rapidly to a normal maintenance dose of $0.5 \mu \mathrm{g}$ daily. Thus the basis of $1,25(\mathrm{OH})_{2} \mathrm{D}_{3}$ resistance in this patient might be regarded as "substrate deficiency" rather than end-organ insensitivity.

Dietary calcium seems to have played a critical role in the patient's bone disease responding to $1,25(\mathrm{OH})_{2} \mathrm{D}_{3}$. This is unlike our earlier experience with the use of $1,25(\mathrm{OH})_{2} \mathrm{D}_{3}$ in treating renal bone disease when supplementation with calcium had little effect on outcome. "But those patients ate normal diets, whereas this patient's diet, though seeming to contain sufficient calcium, probably had less available for absorption perhaps because of the chapatti flour. Nevertheless, estimates of dietary intake are notoriously unreliable, and some authorities argue that the UK recommended daily intake of calcium is anyway too low. ${ }^{18}$

This case also illustrates some of the ways that $1,25(\mathrm{OH})_{2} \mathrm{D}_{3}$ may act. The effects of $1,25(\mathrm{OH})_{2} \mathrm{D}_{3}$ on the intestinal absorption of calcium seen in this patient are well known. More controversial are the effects of $1,25(\mathrm{OH})_{2} \mathrm{D}_{3}$ on bone and the secretion of parathyroid hormone. Receptors for $1,25(\mathrm{OH})_{2} \mathrm{D}_{3}$ may be present on parathyroid gland cells, ${ }^{19}$ and there is some experimental evidence that $1,25(\mathrm{OH})_{2} \mathrm{D}_{3}$ may act directly to suppress parathyroid hormone secretion." ${ }^{20}$

Our patient's plasma concentrations of immunoreactive parathyroid hormone did not fall when $1,25(\mathrm{OH})_{2} \mathrm{D}_{3}$ concentrations rose during treatment until calcium supplements were given. This suggests that the ability of $1,25(\mathrm{OH})_{2} \mathrm{D}_{3}$ to suppress the secretion of parathyroid hormone in man depends on increasing extracellular concentrations of calcium rather than on the presence of $1,25(\mathrm{OH})_{2} \mathrm{D}_{3}$.

The actions of $1,25(\mathrm{OH})_{2} \mathrm{D}_{3}$ on bone include the stimulation of bone resorption in vitro, but there is little evidence that nontoxic doses have this effect. Surprisingly, there is no convincing evidence that $1,25(\mathrm{OH})_{2} \mathrm{D}_{3}$ directly stimulates mineralisation of bone. Our patient's lack of response to $1,25(\mathrm{OH})_{2} \mathrm{D}_{3}$ alone suggests that insufficient dietary calcium might cause osteomalacia despite the presence of adequate supplies of vitamin D.

We thank the National Kidney Research Fund and the Wellcome Trust for their support of this work. Supplies of $1,25(\mathrm{OH})_{2} \mathrm{D}_{3}$ were kindly provided by Roche Products.

Requests for reprints should be addressed to: J A Kanis, Department of Human Metabolism and Clinical Biochemistry, University of Sheffield Medical School, Beech Hill Road, Sheffield S10 2RX.

\section{References}

${ }^{1}$ Haussler MR, McCain TA. Basic and clinical concepts related to vitamin D metabolism and action. N Engl f Med 1978;297:974-83, 1041-50.

2 Bordier P, Pecher MM, Hesse R, Marie P, Rasmussen H. Response of adult patients with osteomalacia to treatment with crystalline $1 \alpha$ hydroxyvitamin D. $N$ Engl f Med 1974 ;291:866-71.

${ }^{3}$ Henderson RG, Russell RGG, Ledingham JGC, et al. Effects of 1,25dihydroxycholecalciferol on calcium absorption, muscle weakness and bone disease in chronic renal failure. Lancet 1974; ; :379-84.

${ }^{4}$ Long RG, Varghese Z, Meinhard EA, Skinner RK, Wills MR, Sherlock S. Parenteral 1,25-dihydroxycholecalciferol in hepatic osteomalacia. $\mathrm{Br}$ Med f 1978; ; :75-7.
5 Juttman JR, Barth JD, Birkenhager JA. Treatment of anti-convulsant osteomalacia with $1 \alpha$-hydroxycholecalciferol. Br Med $\mathcal{f} 1977 ; \mathrm{i}: 577$.

${ }^{6} \mathrm{Kanis}$ JA, Cundy T, Earnshaw M, et al. Treatment of renal bone disease with $1 \alpha$-hydroxylated derivatives of vitamin $\mathrm{D}_{3} . Q 7 \mathrm{Med} 1979 ; \mathbf{4 8}$. 289-322.

Fraser D, Kooh SW, Kind HP, Holick MF, Tanaka Y, DeLuca HF Pathogenesis of hereditary vitamin D-dependent rickets. $N$ Engl f Med $1973 ; \mathbf{2 8 9}: 818-22$.

${ }^{8}$ DHSS. Recommended intakes of nutrients for the United Kingdom. Reports on public health and medical subjects. London: HMSO, 1969:120.

${ }^{9}$ Penfold WAF, Keynes WM. Use of a standard fatty meal as a test of fat absorption. Ann Surg 1971;173:157-63.

10 Woods CG, Morgan DB, Paterson CR, Gossman HH. Measurement of osteoid in bone biopsy. F Pathol Bacteriol 1968;95:441-7.

11 Wills MR, Day RC, Phillips JB, Bateman EC. Phytic acid and nutritional rickets in immigrants. Lancet 1972; : $: 771-3$.

12 Kanis JA, Russell RGG, Smith R. Physiological and therapeutic differences between vitamin D, its metabolites and analogues. Clin Endocrinol 1977;7, suppl: 191-201.

${ }^{13}$ Marx SJ, Spiegel AM, Brown EM, et al. A familial syndrome of decrease in sensitivity to 1,25-dihydroxy vitamin D. 7 Clin Endocrinol Metab $1978 ; 47: 1303-10$.

14 Brooks $\mathrm{MH}$, Bell NH, Love L, et al. Vitamin D dependent rickets type II. $N$ Engl F Med 1978;298:996-9.

15 Zerwerkh JE, Glass K, Jowsey H, Pak CYC. A unique form of osteomalacia associated with end organ refractoriness to 1,25-dihydroxyvitamin $\mathrm{D}$ and apparent defective synthesis of 25 -hydroxyvitamin $\mathrm{D}$. 7 Clin Endocrinol Metab 1979;49:171-5.

${ }^{16}$ Rosen JF, Fleishman AR, Fineberg L, Hamstra A, DeLuca HF. Rickets with alopecia : an inborn error of vitamin D metabolism. $\mathcal{F}$ Pediatr 1979 ; 94:729-35.

17 Lieberman UA, Samuel $R$, Halabe A, et al. End-organ resistance to 1,25dihydroxycholecalciferol. Lancet 1980;i:505-7.

18 Nordin BEC. Calcium, phosphate and magnesium metabolism. Nordin BEC, ed. Edinburgh: Churchill Livingstone, 1976:21-22.

19 Henry H, Norman AW. Studies on mechanism of action of calciferol VII localisation of 1,25 dihydroxyvitamin $\mathrm{D}_{3}$ in chick parathyroid glands. Biochem Biophys Res Comm 1975;62:781-8.

21) Chertow BS, Baylink DJ, Wergedal JE, Su MHH, Norman AW. Decrease in serum immunoreactive parathyroid hormone in rats and in parathyroid hormone in vitro by 1,25 dihydroxycholecalciferol. $\mathcal{f}$ Clin Invest $1975 ; 56: 668-78$.

(Accepted 22 February 1982)

\section{Miniprint pages}

If you want to read in full size the articles that appear in miniprint in your edition of the $B M \mathcal{F}$ you may:

- Change your edition of the journal. If you want to read practice observed articles regularly you need the Practice Observed edition; if you want to read clinical research articles you need the Clinical Research edition.*

- Write to the publishing department for a full-sized copy of an individual article that appears in miniprint in your edition.

- Take advantage of the journal's special offer on magnifying glasses. Some of these are still available (price $£ 1.50$ including post and packaging) from the publishing department.

- Subscribe to a set of full-size pages to be sent at the end of each month. This service (subscription $f 10$ a year) is designed mainly for readers who want to bind their journals.

- Arrange among your colleagues (in a group practice or hospital department, for example) for one person to subscribe to the alternative edition of the $B M \mathcal{~}$. Then everyone in the group will have access to both editions.

The editorial content of both editions is the same: the only difference is in the size of the print of the clinical research and practice observed sections.

* This arrangement does not apply to permanently retired or associate *This arrangement does not apply to permanently retired or associa
members of the BMA, who receive the compact edition of the $B M \mathcal{F}$. 